\title{
Monetary institutions and inflation performance: cross-country evidence
}

\section{Bilin Neyapti}

To cite this article: Bilin Neyapti (2012) Monetary institutions and inflation performance: cross-country evidence, Journal of Economic Policy Reform, 15:4, 339-354, DOI: 10.1080/17487870.2012.731805

To link to this article: http://dx.doi.org/10.1080/17487870.2012.731805

\section{曲 Published online: 08 Nov 2012.}

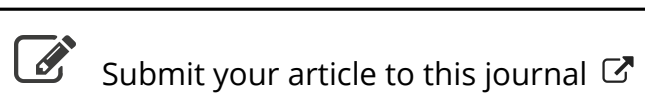

Llll Article views: 223

Q View related articles $\asymp$

Citing articles: 2 View citing articles 


\title{
Monetary institutions and inflation performance: cross-country evidence
}

\author{
Bilin Neyapti* \\ Department of Economics, Bilkent University, 06800 Bilkent, Ankara, Turkey
}

\begin{abstract}
This paper presents an empirical investigation of the effectiveness of the institutional frameworks of monetary policy in achieving and maintaining price stability. The institutional frameworks considered are central bank independence (CBI), inflation targeting (IT), currency boards (CB) and monetary unions (MU). Against the vast literature that argues for the price stabilizing effects of each of these institutions, the empirical evidence presented here suggests that countries that have adopted the IT and $\mathrm{CB}$ regimes have, on average, been associated with lower inflation rates than others during the past decade. This finding is robust to various control variables, while governance appears to be a substitute to formal mechanisms.
\end{abstract}

Keywords: monetary institutions; inflation

JEL Classifications: E5, O1

\section{Introduction}

It is no mystery to a social scientist that high inflation is costly because it worsens income distribution, raises uncertainty, deters investment and growth and causes macroeconomic instability. In a seminal work, Bailey (1956) presents a framework to measure the welfare costs of high inflation; Fischer (1981), Cooley and Hansen (1989), and Lucas (2000) argue that these welfare effects can be quite high. The key role that price stability plays in achieving a healthy macroeconomic environment has been pointed out in numerous other studies (including, for example, Cukierman 1982, Fischer 1981, Barro 1996).

The transition to the flexible exchange rate system during the 1970 s led to a revision of the monetary policy frameworks around the world. Pursuant to this and to the two major oil crises during the 1970s, many countries experienced episodes of increasing inflation rates that had more severe effects on some than others. In the wake of the rational-expectations revolution in the 1980s, adopting a nominal anchor gained increasing acceptance as an essential tool of achieving price stability. In many developing economies, policy efforts to control inflation involved a money stock or exchange rate anchor during the 1980s and 1990s. Eradicating the inflation inertia and preventing the unpleasant monetary arithmetics, however, was not easy in many cases (see, for example, Bruno et al. 1988, Calvo and Vegh 1999, Barnea and Liviathan 2008); as any public-good, price stability tended to be underprovided.

Pioneered by Barro and Gordon (1983), Taylor (1993) and Kydland and Prescott (1997), the 'rules versus discretion' debate highlighted the necessity of establishing

\footnotetext{
*Email: neyapti@bilkent.edu.tr
} 
credible commitment mechanisms for achieving price stability in order to curb fiscal dominance or the temptation of short-sighted governments to generate surprise inflation. The need to set the rules of the game for monetary policy via formal institutional mechanisms gained prominence during the 1990s. As a result of reforming the monetary institutional frameworks, inflation around the world has declined significantly during the 2000s. This accompanies the observation that the divergent development processes of several developing countries start to exhibit some convergence to those of the developed countries. ${ }^{1}$

This study presents an empirical investigation of the impact on price stability of formal monetary institutions, namely legal central bank independence (CBI); inflation targeting (IT); currency boards (CB); and monetary unions (MU), during the past decade. All of these institutional arrangements reflect effort to reduce discretion in monetary policy by way of increasing transparency and accountability and, hence, credibility (as in the case of CBI and IT); or adopting a hard peg regime (in case of $\mathrm{CB}$ and $\mathrm{MU}$ ) via legal arrangements, even though the latter implies loss of monetary policy independence. During the $2000 \mathrm{~s}$, the number of independent central banks has been on the rise, although there has been significant variation in degrees of independence. ${ }^{2}$ Meanwhile, the number of countries that adopted the IT regime has also risen. In addition, the members of monetary unions have increased remarkably with the establishment of the European Union (EU). Several countries have adopted a combination of these monetary institutions, especially the combination of CBI and IT. Parkin and Bade (1978), Grilli et al. (1991), Cukierman et al. (1992, 2002), Banaian et al. (1998), de Haan and Kooi (2000), Arnone et al. (2007), Cukierman (2008), Eijffenger (1993, 1995), among others, have argued and empirically demonstrated that the independence of a central bank with the primary mandate of price stability indeed helps achieve that objective. Cukierman et al. (1992, 2002) demonstrate that de jure versus de facto measures of CBI matter in the developed and less developed set of countries, respectively. ${ }^{3}$ Mishkin (2004) and Mishkin and SchmidtHebbel (2007) review the conditions for the effective implementation of the IT regime and their important role in the experiences of countries with stabilizing inflation under this regime. Defining a measure of core inflation, target horizon and target band, as well as escape clauses, are among the main features of the IT regime, highlighting the operational aspects of monetary policy. It is argued that transparency and accountability are essential for IT's successful implementation, which points at its symbiotic relationship with CBI especially with regard to instrument independence. The success of both CBI and IT also depends, in a good measure, on financial market development and lack of fiscal dominance. ${ }^{4}$ Furthermore, the status of informal institutions, or norms, are agreed to be at least as important as formal ones in attaining the goal of price stability.

In view of the failing experiences of many countries with exchange rate anchoring during the 1980s and 1990s (see, for example, Hamann, 2001 and Husain et al. (2005)), $\mathrm{CBs}$ and MUs emerged as institutional mechanisms of pegging a currency to a hardcurrency. It is, however, argued that the success of hard-peg mechanisms requires stringent circumstances, while the benefits of $\mathrm{CB}$ usually exceed the costs of losing monetary policy independence for small countries (see, for example, Gertchev, 2002, and Hanke, 2002) that peg their currency to the currency of the major trading partner. For the benefits of MU, Edwards (2006) argues that meeting an extended set of conditions originally discussed in Mundell (1961) for the optimal currency area is crucial.

Against the background of the numerous studies that have focused on the roles of specific monetary arrangements on price stability, the current paper is the thought to be the first that examines their relative contribution to this objective. Using cross-sectional 
data on up to 166 countries, and after controlling for the main structural characteristics of countries, we show that countries that have either IT or CB regimes have had lower than average inflation rates during the 2000s. The current study also shows that neither CBI nor MU seem to add to low inflation performance significantly. Inflation variability, on the other hand, is observed to be higher the higher is CBI and the smaller is the country.

The empirical evidence provided in this paper sheds further light on the importance of first, having some sort of formal commitment device to price stability, and, second, the role of the IT regime in maintaining price stability, given that low inflation was already achieved by many countries by the 2000 s. For small countries, on the other hand, the CB regime helps to maintain low inflation rates. These findings can help form policy advice regarding what works best under relatively low inflation environment. In what follows, Section 2 presents the data and empirical analysis and Section 3 concludes.

\section{Data, methodology and empirical evidence}

Section 2.1 provides the description of data and methodology. Section 2.2 reports the empirical findings and presents robustness checks.

\subsection{Data and methodology}

The average inflation rate around the world has been substantially reduced in the $2000 \mathrm{~s}$ as compared with the previous decades (see Figure 1, where each legend shows a country's average inflation rate, in logs, for the indicated decade). ${ }^{5}$ The average inflation rates (in plain terms) for these periods (based on 134, 164 and 167 countries, respectively) were 39\%, 78\% and 27\%, respectively. Excluding Zimbabwe (a clear outlier) from the 2000s sample leads to a world-average inflation rate of approximately only $7.5 \%$.

To avoid the biases that may arise from the large variation in the (CPI) inflation data, we follow Cukierman et al. $(1992,2002)$ in using a transformed version of inflation: $D=[\pi /(1+\pi]$. This transformation is one-to-one and reduces the range of inflation data to 0 to 1. ${ }^{6}$ The Appendix reports the values of $D$ and along with the list of countries used in empirical analysis below.

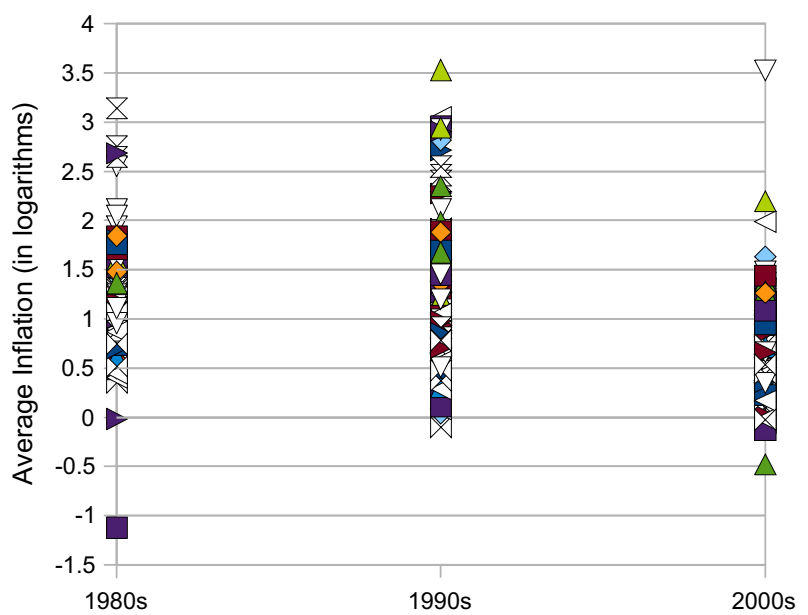

Figure 1. Inflation (in logs) performance during the past three decades. 
The indices of $C B I$, ranging between zero and one, as well as the dummy variables that take the value of 1 in cases of $I T, C B$ and/or $M U$ regimes are listed in the Appendix for each country in the data set. The CBI data compiled by Arnone et al. (2007) for 2003 is based on the original coding methods of Grilli et al. (1991) and Cukierman et al. (1992), which identify a comprehensive and widely used set of criteria to measure CBI. ${ }^{7}$ We take the Roger and Stone (2005) study as the source of the list of the countries that have the $I T$ regime during the 2000 s, to which we add Turkey, which had an implicit IT regime until 2006 and switched to an explicit IT regime thereafter; and the Euro area. $C B$ dummies are based on the IMF classification of the exchange rate regimes and monetary policy frameworks. ${ }^{8} M U$ dummies are also obtained from the International Monetary Fund (IMF) (2005) and cover the Central African Economic and Monetary Union, the Eastern Caribbean Currency Union, and the West African Economic and Monetary Union in addition to the EMU.

Because the institutional data are available mostly on a cross-section basis, inflation rates $(D)$ are also calculated in averages over the period 2000-2006, where available. The number of observations common to most variables is 166 , but it is reduced to 137 due to the availability of inflation or CBI data. ${ }^{9}$ The inclusion of the macroeconomic data also reduces the sample to 72 countries, due to the lack of availability of the data for the latter. The sample in each case is comprised of a well-balanced set of data on developed and less developed countries.

Table 1 shows that all these monetary institutions, with the exception of $C B$, are positively correlated with the dummy for developed countries $(D C) .{ }^{10}$ The especially high correlation between $I T$ and $D C$ appears consistent with the administrative sophistication needed for an effective implementation of $I T$. In addition, both $C B I$ and $M U$ show notable positive associations with IT; the first of which is consistent with the nature of $I T$ requiring instrument independence of the central bank, while the second is mainly reflecting the EU sample, which is considered under $I T$ here due to the price-stability objective defined by the Maastricht Treaty, even though the implementation features may differ from an IT regime. The table also shows, however, that $M U$ countries that exclude the EU countries do not show correlations with the rest of the institutions.

Given the cross-sectional nature of the data, this paper investigates the impact of monetary institutions on inflation using an OLS regression, after correcting for possible heterogeneity in the error terms using the White-heteroskedasticity method. It is worthwhile stating that the focus of the paper is to explore the significance of associations between the institutional frameworks and last decade's inflation performance around the world, rather than exploring a causal relationship between these variables. Indeed, exploring causality in macroeconomic analyses that involve institutional quality is usually a futile task, and beyond the scope of the current paper, since the adoption of formal institutions is dynamically interwoven with economic development and stability. ${ }^{11}$

Table 1. Correlations among monetary institutions.

\begin{tabular}{lrrllll}
\hline & CBI & CU & MU(woEU) & CB & IT & DC \\
\hline CBI & 1 & & & & & \\
MU & 0.40 & 1 & & & & \\
MU(woEU) & -0.04 & 0.33 & 1 & 1 & & \\
CB & 0.04 & -0.08 & -0.03 & -0.13 & 1 & \\
IT & 0.44 & 0.52 & -0.06 & -0.11 & 0.75 & 1 \\
DC & 0.51 & 0.51 & -0.04 & -0.11 \\
\hline
\end{tabular}


The basic regression to be estimated is as follows:

$$
D_{i}=\alpha+\beta_{1} M U_{i}+\beta_{2} C B_{i}+\beta_{3} C B I_{i}+\beta_{4} I T_{i}+\varepsilon_{i}, i=1, \ldots, 166
$$

where $\alpha$ is the constant term, $\beta_{i} \mathrm{~s}$ are the coefficient terms that are hypothesized to be negative, $\varepsilon_{i}$ s are the random error terms and $i$ is the country indicator.

In view of the higher likelihood of success of $\mathrm{CB}$ in small countries than others, the regression is extended to control for a dummy variable for small-countries $(S)$. In addition, to account for possible omitted variables, the developed country dummy $(D C)$ is also added. ${ }^{12}$ Table 2 reports these regression results, where the last column includes the extended version of equation (1).

One could argue that monetary policy variables such as the exchange rate regime, money growth rate can be used as explanatory variables in estimating inflation. These variables, however, are themselves endogenous to the institutional frameworks that are adopted with the purpose of shaping those policies in turn. Hence, following similar empirical models, such as Cukierman et al. (1992, 2002), our empirical model focuses on the role of institutional aspects of monetary policy in explaining the variation in inflation across countries. We nevertheless test the robustness of our findings including past inflation, deficit and openness.

\subsection{Estimation results}

Table 2 presents the regressions of inflation $(D)$ on each of the institutions separately, in columns I to IV; as well as on all of them, in column V. The estimation results reported in the table supports the hypothesis that all the monetary institutions considered in this paper, except for $C B I$, are, on average, associated with lower inflation rates during the $2000 \mathrm{~s}$ than those that lack them. The negative association remains statistically significant only for the $I T$ and $C B$ regimes, however, when all the institutions are jointly employed to explain inflation. The addition of the $D C$ and $S$ dummies does not change this finding, although both $S$ and $D C$ are also found to have significant negative associations with inflation. This result is predictable in case of developed countries, where macroeconomic institutions are generally consistent with policy credibility; for small economies, however, a general explanation would not be appropriate given the large variation in their geography and the level of development. In an attempt to explore whether there is a threshold value of $C B I$ over which $C B I$ is effective, column IIIa also reports that for the case of high $C B I(C B I>0.6), C B I$ is indeed significant, though at the $10 \%$ level. ${ }^{13}$

Several sensitivity tests are performed: When the regressions are repeated without excluding the countries with high inflation rate and with a dummy for Zimbabwe (which is an outlier), the R-bar-squared rises to 0.65 (due to the high positive significance of the Zimbabwe dummy) although the reported findings remain virtually unchanged. ${ }^{14}$ In addition, the regression model (equation (1)) is expanded by using interactive terms (such as between $C B$ and $S$; and between $C B I$ and $I T^{15}$ ); these interactive variables neither improve the fit of the regression (the results reported above remain the same) nor are themselves significant, and therefore those results are not reported. Furthermore, column I is repeated by excluding the EU sample from the set; the resulting countries with $M U$ still exhibit a negative significant relationship with $D$, as reported in Column $\mathrm{I}$, although it loses its significance in Columns $\mathrm{V}$ and VI, as reported above. 


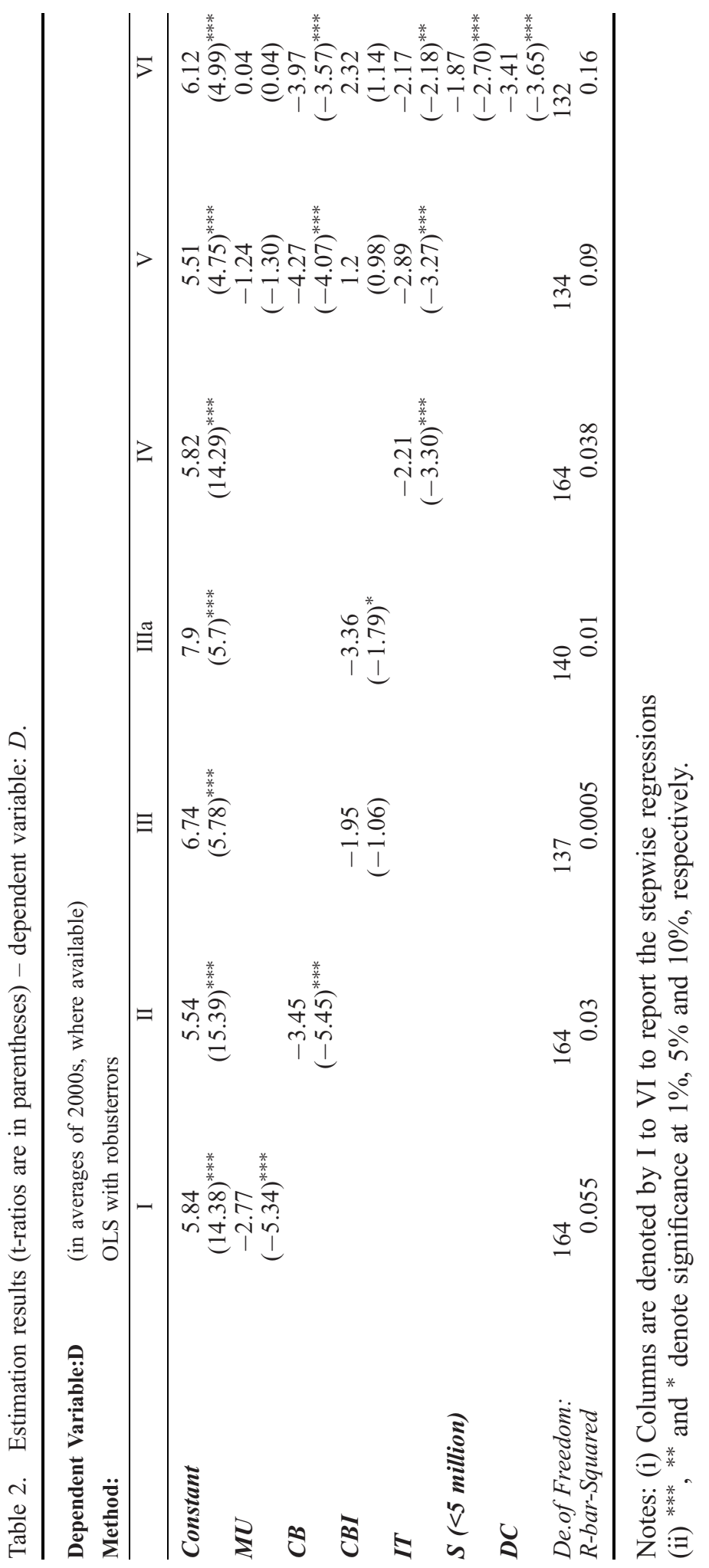




\subsubsection{Robustness}

One may also consider several other variables that may affect the inflation rate besides the monetary institutions; the candidates are the past inflation rates, openness and past deficits. In addition, it may be argued that the general quality of governance, ${ }^{16}$ rather than of only monetary institutions, may be related to low inflation rates. To test these hypotheses, equation (2) presents a specification that includes the initial values (in 1990s' averages) of the above-listed macroeconomic variables; the governance index (gov) for the 2000s; and the interactive terms of gov with the monetary institutions $(M I): C B, M U, C B I$ and $I T$.

$$
\begin{gathered}
D_{t i}=\alpha+\beta_{j} M I_{j, t i}+\gamma \text { gov }_{t i}+\theta_{j}\left(M_{j, t i}^{*} \text { gov }_{t i}\right)+ \\
a\left(D_{t-1, i}\right)+b\left(\text { Deficit } / G D P_{t-1, i}+c\left(\text { openness }_{t-1, i}\right)+\eta_{i}\right.
\end{gathered}
$$

where $j$ stands for the four types of $M I$ 's; $i$ stands for different countries as in equation (1); and $\eta_{i}$ is the error term. ${ }^{17}$ Time subscripts $t$ and $t-1$ refer to the decade averages of the 2000s and 1990s, respectively. The model can be extended to include the dummies for three groups of countries: developed sample, transition sample (that were in the 1990s) and small countries (with less than 5 million people), the last of which is relevant specifically for the success of $C B$. However, all these dummies are found insignificant in the estimation and hence are dropped from the model.

According to Brambor et al. (2006), the lack of significance of $\beta_{j}$ in equation (2), or the significance of the coefficient of the interactive variable alone, is not sufficient to infer about the significance the $M I$ variables. In view of this, one can measure the marginal effect of $M I$ variables on $D$ by constructing confidence intervals for the estimates of $\left(\beta_{j}+\theta_{j}\right)$ over the possible values of gov $_{j}$; if the interval lies above (below) the zero line, then the effect is significantly positive (negative).

Table 3 reports the averages of $D$, as well as the macroeconomic control variables by country groups during the 2000 s. The table indicates that $D$ is notably higher in the developing countries (LDC, defined as 1-DC), where especially gov is also much smaller than the rest of the country groups. In addition, it is noteworthy that while average $C B I$ in this period is $0.85,0.53$ and 0.74 in EU, Small and DC groups, it is 0.55 in the LDCs. The observation that it is the institutional variables, rather than country characteristics, that account for inflation differentials makes the case for reforming monetary institutions stronger.

Focusing on the estimation of the extended model, the first two columns of Table 4 (regression I), reveal that the basic results (significance of $C B$ and $I T$ ) reported earlier (based on equation (1)) remains, where, in addition, past deficits are also found to be positively significant and openness is negatively significant. When gov is included (regression II), however, the significance of these terms is lost, whereas gov and past deficits appear significant with the expected negative and positive signs, respectively. The

Table 3. The 2000s' average of the macroeconomic indicators by country group.

\begin{tabular}{lccccc}
\hline & \multicolumn{5}{c}{ 2000s average } \\
\cline { 2 - 6 } Country Group & $D$ & Def/GDP & open & gov & No.of Coutries \\
\hline EU & 3.6 & -1.25 & 112 & 0.81 & 26 \\
Small (<5 Mill) & 4.3 & 0.19 & 114 & 0.59 & 63 \\
DC & 2.1 & 0.81 & 110 & 0.89 & 24 \\
LDC & 7.3 & -1.08 & 91 & 0.46 & 146 \\
\hline
\end{tabular}


Table 4. Estimation results of equation (2).

\begin{tabular}{|c|c|c|c|c|c|c|}
\hline \multirow[b]{2}{*}{ RHS: } & \multicolumn{2}{|r|}{ I } & \multicolumn{2}{|r|}{ II } & \multicolumn{2}{|c|}{ III } \\
\hline & Coeff. & t-stat & Coeff. & t-stat & Coeff. & t-stat \\
\hline Constant & 5.93 & $(3.37)^{* * *}$ & 9.45 & $(6.38)^{* * *}$ & 7.64 & $(1.98)^{* * *}$ \\
\hline$M U$ & -0.57 & $-(0.69)$ & -0.27 & $-(0.40)$ & -0.52 & $-(0.14)$ \\
\hline$C B$ & -1.54 & $-(1.95)^{*}$ & -1.40 & $-(1.23)$ & -90.60 & $-(3.05)^{* * *}$ \\
\hline$I T$ & -4.10 & $-(4.17)^{* * *}$ & -1.06 & $-(1.24)$ & -8.15 & $-(4.07)^{* * *}$ \\
\hline$C B I$ & 3.94 & (1.41) & 5.09 & $(2.17)^{* *}$ & 10.28 & (1.42) \\
\hline gov & & & -10.58 & $-(5.51)^{* * *}$ & -6.69 & $-(1.20)$ \\
\hline CBI $I^{*}$ gov & & & & & -11.78 & $-(1.20)$ \\
\hline$I T^{*}$ gov & & & & & 11.29 & $(3.63)^{* * *}$ \\
\hline$C B^{*}$ gov & & & & & 156.80 & $(3.02)^{* * *}$ \\
\hline$M U^{*}$ gov & & & & & 0.37 & $(0.08)$ \\
\hline Deficit/GDP (90s) & 0.09 & $(2.29)^{* *}$ & 0.12 & $(1.80)^{*}$ & 0.13 & $(1.83)^{*}$ \\
\hline$D(90 s)$ & 0.00 & $(0.56)$ & 0.00 & $-(0.80)$ & 0.00 & $-(0.70)$ \\
\hline opennness (90s) & -0.02 & $-(2.49)^{* *}$ & -0.01 & $-(0.96)$ & 0.00 & $-(0.63)$ \\
\hline Number of Observations: & 72 & & 72 & & 72 & \\
\hline R-bar-squared: & 0.23 & & 0.43 & & 0.45 & \\
\hline
\end{tabular}

Note: ${ }^{* * *},{ }^{* *}$ and ${ }^{*}$ denote significance at $1 \%, 5 \%$ and $10 \%$, respectively.

goodness of fit of the regression rises to 0.43 . The unrestricted version of this model reported in regression III also shows the recovered significance of both $C B$ and $I T$ at the $1 \%$ level. Among the control variables, the past deficit remains to be the only one that is significant, which is at the $10 \%$ level. To be able to interpret the interactive terms' significance, however, one needs to look at the confidence intervals in Figure 2.

The $10 \%$ confidence intervals in Figure 2 confirm the insignificance of both $M U$ and $C B I$ since neither of them is significant for any range of gov. On the other hand, $C B$ and $I T$ have significant negative effects on inflation for especially low levels of gov. This implies that high quality of governance lowers the contribution of both $C B$ or $I T$ to price stability, which means that in countries where informal institutions are developed (reflected by high gov) the adoption of formal monetary institutions appears less crucial for attaining low inflation (the threshold levels of gov for rendering $C B$ and $I T$ significant is as low as 0.2 and 0.3 , respectively on a scale between 0 to 1$).^{18}$

A further robustness check of the results is carried out by an alternative estimation technique, where the experience of banking crises, ${ }^{19}$ and the average levels of inflation and budget deficit during the 1990s is used to instrument the MIs during the 2000s. The estimations results do not indicate any improvement with this approach, with no significant finding observed.

As an additional test, we ran the set of regressions reported in Table 2 by replacing the dependent variable with the coefficient of variation ${ }^{20}$ in inflation in order to explore the sensitivity of inflation variability to $C B, M U, C B I$ and $I T$ during the $2000 \mathrm{~s}$. In these regressions, except for $M U$, none of the $M I$ 's is found significantly negative. This result is likely to be dominated by the longer decision and/or action lags of the EU's monetary policy processes due to its union-wide considerations. Including the country group dummies leads to the following interesting observations. First, $M U$ loses its significance, but both $C B I$ and the small country dummy is observed to have significant association with higher than average inflation variability. Second, developed countries are observed to be 

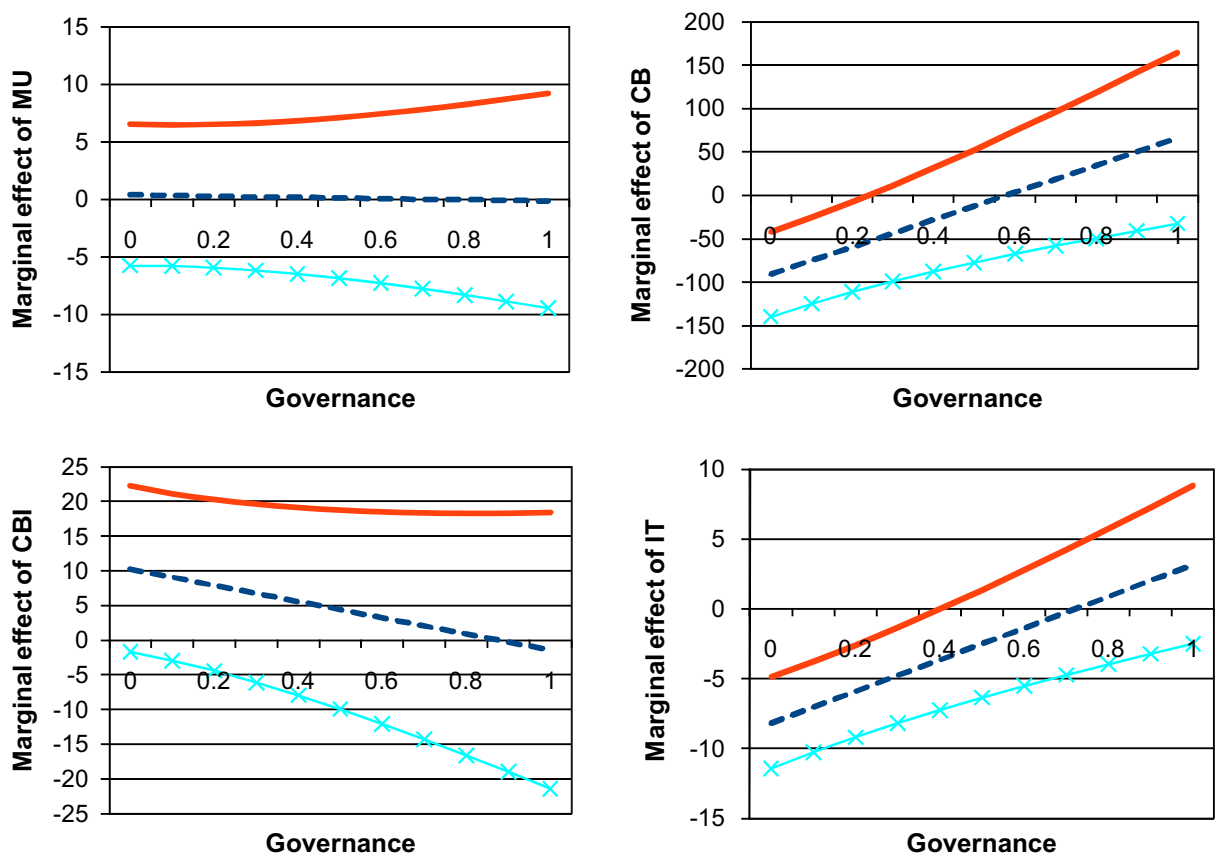

Figure 2. Marginal effects of $M I_{j} \mathrm{~s}$.

associated with significantly lower inflation variability than others, as expected. ${ }^{21}$ Macroeconomic indicators considered in equation (2), however, do not have any explanatory power for inflation variation.

To sum up, even after controlling for the main macroeconomic variables and country groupings that may affect inflation performances across the world, this paper demonstrates that formal commitments to price stability matter. More specifically, countries that adopted inflation targeting and currency board regimes have managed to maintain lower inflation rates than others during the 2000s. Informal institutions also matter, however, as reflected in the significant effect of governance in achieving price stability. The results reported here pose reinforcing evidence in favor of the rule versus discretion.

\section{Conclusion}

The financial sector is abundant with transaction costs and hence incomplete contracts. A fundamental transaction cost arises from the uncertainty of the value of money due to high and variable inflation, whose costs are analyzed widely in the literature. After the hyper- and persistently high inflation episodes of many countries around the world in the preceding period, the first decade of the 2000s has witnessed a notable increase in price stability around the world. Various monetary institutions designed as agents of credible monetary policy have played a major role in this phenomenon. As Chami et al. (2010) point out, rather than supply creating its own demand, financial instruments, and more broadly financial institutions, develop in response to demand arising for them in the financial markets. Likewise, monetary policy institutions studied here are usually formed to reduce the large costs of inflation that generate society-wide interest to avert them (see, Posen, 1995). Achieving a stable currency, in turn, facilitates the development of the rest of the financial system by contributing to the enforceability of nominal contracts. 
Against the literature that argues for the effectiveness of various institutions of monetary policy individually, this paper explores their relative roles in achieving price stability. The cross-sectional evidence based on a large sample of countries indicates that countries that have adopted inflation targeting and currency board regimes have, on average, achieved significantly lower inflation rates than the rest during the 2000s. These results are robust to the inclusion of control variables, while quality of governance, a general indicator of informal institutions, appears to be a good substitute for formal monetary institutions. The adoption of formal institutions of price stability therefore seems a sufficient but not a necessary condition in case informal institutions are well developed. In cases where the low inflation culture is not well-established (reflected in low governance levels), inflation targeting and currency board regimes seem to be effective formal mechanisms to achieve price stability.

\section{Notes}

1. See Lin and Rosenblatt (2012).

2. See the Appendix for the list of countries and their monetary institutions.

3. See Neyapti (2010) for a review of this literature.

4. See, for example, Posen (1995) and Neyapti (2003) for the case of CBI.

5. The data are compiled from the World Bank Development Indicators online.

6. An alternative could be to use the logs (or even the levels) of inflation, which does not alter the results reported below.

7. The criteria list in Cukierman et al. (1992) covers, in broad terms, the objective, chief executive officer, lending and policy formulation of the central bank. Grilli et al. (1991) distinguish between the economic and political aspects of CBI.

8. See http://www.imf.org/external/np/mfd/er/2008/eng/0408.html, where it is stated that 'a monetary regime based on an explicit legislative commitment to exchange domestic currency for a specified foreign currency at a fixed exchange rate, combined with restrictions on the issuing authority to ensure the fulfillment of its legal obligation'.

9. The descriptive statistics of $D$ and the monetary institutions subject to this study are as follows:

\begin{tabular}{lcc}
\hline & Mean & $\begin{array}{c}\text { Std } \\
\text { Error }\end{array}$ \\
\hline$D$ & 0.07 & 0.10 \\
$M U$ & 0.15 & 0.36 \\
$C B$ & 0.09 & 0.29 \\
$C B I$ & 0.58 & 0.20 \\
$I T$ & 0.18 & 0.38 \\
\hline
\end{tabular}

10. $D C$ takes the value of 1 for countries that IMF classifies as the advanced economies. Source: World Economic Outlook, Sept. 2011.

11. Posen (1995), for example, asserts that it is not CBI but financial opposition to inflation (foi) that explains low inflation. Likewise, Berdiev at al. (2012) argue that the choice of exchange rate regime is endogenous to political and institutional factors.

12. We do not use a dummy for transition economies since countries that were in transition in the $1990 \mathrm{~s}$ are included in the list of developing countries in the 2000s.

13. Column IIIa reports results with a zero constraint for the $C B I$ values that are lower than 0.6. A similar reporting can be found in Cukierman et al. (2002) for liberalization index (CLI).

14. Angola, Belarus, Congo and Zimbabwe all had more than $100 \%$ inflation at least in one year during the 2000s. Zimbabwe remains to be the only one with a high inflation rate as of 2006 .

15. The first of these accounts for the fact that $\mathrm{CB}$ is mostly effective for small countries and effective implementation of the IT regime requires CBI.

16. Governance indices are provided by Kaufman et al. (2008), based on surveys that report six different measures of the quality of political stability; control of corruption; rule of law; voice and accountability; government effectiveness; and regulatory quality. 
17. Small country and developed country dummies are dropped to focus on the effects of structural variables. When included, their coefficients are observed to be insignificant.

18. In Canada, Japan and United Kingdom, for example, CBI is $0.63,0.44$ and 0.69 , respectively; whereas the level of gov, representing informal institutional quality is all above 0.8 .

19. Data are based on Leaven and Valencia (2008).

20. The coefficient of variation is measured as standard deviation divided by the sample mean, which is a measure of variation that is comparable across.

21. These regressions are available from the author upon request.

\section{References}

Arnone, M., Laurens, B.J., Segalotto, J.-F., and Sommer, M., 2007. Central Bank autonomy: lessons from global trends. IMF Working Paper 07/88.

Bailey, M.J., 1956. The welfare cost of inflationary finance. The Journal of Political Economy, 64 (2), 93-110.

Banaian, K., Burdekin, R.C.K., and Willett, T.D., 1998. Reconsidering the principal components of Central Bank Independence: the more the merrier? Public Choice, 97 (1/2), 1-12.

Barnea, E. and Liviathan, N., 2008. The chronic inflation process: a model and evidence from Brazil and Israel. Journal of Economic Policy Reform, 11 (2), 151-162.

Barro, R. and Gordon, D.B., 1983. Rules, discretion and reputation in a model of monetary policy. Journal of Monetary Economics, 12 (3), 101-121.

Barro, R., 1996. Inflation and growth. Proceedings, Federal Reserve Bank of St. Louis, 78 (5/6), $153-169$.

Brambor, T., Clark, W.R., and Golder, M., 2006. Understanding interaction models: improving empirical analyses. Political Analysis, 14 (1), 63-82.

Bruno, M., Di Tella, G., Dornbusch, R., and Fischer, S., 1988. Inflation stabilization: the experience of Israel, Argentina, Brazil, Bolivia, and Mexico. Cambridge, MA: MIT Press.

Berdiev, A.Z., Kim, Y., and Chang, C.P., 2011. The political economy of exchange rate regimes in developed and developing countries. European Journal of Political Economy, 28 (1), 38-53.

Calvo, G. and Vegh, C.A., 1999. Inflation stabilization and BOP crises in developing countries. NBER Working Paper Series 6925.

Chami, R., Fullenkamp, C., and Sharma, S., 2010. A framework for financial market development. Journal of Economic Policy Reform, 13 (2), 107-135.

Cooley, T.F. and Hansen, G.D., 1989. The inflation tax in a real business cycle model. The American Economic Review, 79 (4), 733-748.

Cukierman, A., 1982. Relative price variability, inflation and the allocative efficiency of the price system. Journal of Monetary Economics, 9 (2), 131-162.

Cukierman, A., 2008. Central bank independence and monetary policymaking institutions - past, present and future. European Journal of Political Economy, 24 (1), 722-736.

Cukierman, A., Neyapti, B., and Webb, S., 1992. Measuring the independence of central banks and its effect on policy outcomes. World Bank Economic Review, 6 (3), 353-397.

Cukierman, A., Miller, G., and Neyapti, B., 2002. Central bank reform, liberalization and inflation in transition economies - an international perspective. Journal of Monetary Economics, 49 (2), 237-264.

De Haan, J. and Kooi, W.J., 2000. Does central bank autonomy really matter: new evidence for developing countries using a new indicator. Journal of Banking and Finance, 24 (4), 643-664.

Edwards, S., 2006. Monetary unions, external shocks and economic performance. a Latin American perspective. International Economics and Economic Policy, 3 (3), 225-247.

Eijffenger, S., 1993. Central bank independence in twelve industrial countries. Banca Nazionale del Lavoro Quarterly Review, 184 (1), 49-89.

Eijffenger, S., 1995. Central bank independence in another eleven countries. Banca Nazionale del Lavoro Quarterly Review, 192 (1), 39-83.

Fischer, S., 1981. Towards an understanding of the costs of inflation. Carnegie-Rochester Conference on Public Policy, 15 (1), 5-42.

Gertchev, N., 2002. The case against currency boards. The Quarterly Journal of Austrian Economics, $5(4), 57-75$.

Grilli, V., Masciandaro, D., and Tabellini, G., 1991. Institutions and policies. Economic Policy, 6 (13), 342-392. 
Hamann, J., 2001. Exchange-rate-based stabilization: a critical look at the stylized facts. IMF Staff Papers, 48 (1), 111-138.

Hanke, S.H., 2002. Currency boards. Annals, AAPSS, 579.

Husain, A., Mody, A., and Rogoff, K.S., 2005. Exchange rate regime durability and performance in developing countries versus advanced economies. Journal of Monetary Economics, 52 (1), 35-64.

International Monetary Fund (IMF), 2005. Fund surveillance over members of currency unions. December.

Kaufmann, D., Kraay, A., and Mastruzzi, M., 2008. Governance matters VII: governance indicators for 1996-2007. World Bank Policy Research Working Papers 4653.

Kydland, F.E. and Prescott, E.C., 1997. Rules rather than discretion: the inconsistency of optimal plans. Journal of Political Economy, 85 (3), 473-491.

Leaven, L. and Valencia, F., 2008. Systemic banking crises: a new database. IMF Working Paper $08 / 224$.

Lin, J.Y. and Rosenblatt, D., 2012. Shifting patterns of economic growth and rethinking development. Journal of Economic Policy Reform, 15 (1), 1-24.

Lucas, R.E.Jr., 2000. Inflation and welfare. Econometrica, 68 (2), 247-275.

Mishkin. F.S., 2004. Can inflation targeting work in emerging market economies. NBER Working Papers 10646.

Mishkin, F.S. and Schmidt-Hebbel, K., 2007. Does inflation targeting make a difference? NBER Working Papers 12876.

Mundell, R., 1961. The theory of optimum currency areas. American Economic Review, 51 (4), 657-665.

Neyapti, B., 2003. Budget deficits and inflation: the roles of central bank independence and financial market development. Contemporary Economic Policy, 21 (4), 458-475.

Neyapti, B., 2010. Macroeconomic institutions and development. Edward Elgar.

Parkin, M. and Bade, R., 1978. Central Bank Laws and Monetary Policy: A Preliminary Investigation. In: M.G. Porter, ed. The Australian Monetary System in the 1970s. Clayton, Australia: Monash University, 24-39.

Posen, A., 1995. Declarations are not enough: financial sector sources of central bank independence. NBER Macroeconomics Annual, 10, 253-274.

Roger, S. and Stone, M., 2005. On target: the international experience with achieving inflation targets. IMF Working Paper 05/163.

Taylor, J.B., 1993. Discretion versus policy rule in practice. Carnegie-Rochester Conference Series on Public Policy, 39 (1), 195-214.

\section{Appendix. Inflation (D) and monetary institutions}

\begin{tabular}{lcccccc}
\hline & $\mathbf{D}$ & $\mathbf{M U}$ & $\mathbf{C B}$ & $\mathbf{I T}$ & $\mathbf{C B I}$ & $\mathbf{S}$ \\
& $\left({ }^{*} \mathbf{1 0 0}\right)$ & $(1)$ & $(1)$ & $(2)$ & & \\
\hline Afghanistan & 12.42 & 0 & 0 & 0 & 0.63 & 0 \\
Albania & 2.60 & 0 & 0 & 0 & 0.75 & 1 \\
Algeria & 2.42 & 0 & 0 & 0 & 0.81 & 0 \\
American Samoa & na & 0 & 0 & 0 & na & 1 \\
Andorra & na & 0 & 0 & 0 & na & 1 \\
Angola & 49.39 & 0 & 0 & 0 & 0.31 & 0 \\
Antigua and Barbuda & na & 0 & 1 & 0 & na & 0 \\
Argentina & 8.16 & 0 & 0 & 0 & 0.75 & 0 \\
Armenia & 2.80 & 0 & 0 & 0 & 0.81 & 1 \\
Aruba & 3.55 & 0 & 0 & 0 & 0.56 & 1 \\
\hline
\end{tabular}


Appendix. (Continued).

\begin{tabular}{|c|c|c|c|c|c|c|}
\hline & $\begin{array}{c}\text { D } \\
\left({ }^{*} 100\right)\end{array}$ & $\begin{array}{c}\text { MU } \\
(1)\end{array}$ & $\begin{array}{l}\text { CB } \\
(1)\end{array}$ & $\begin{array}{l}\text { IT } \\
(2)\end{array}$ & CBI & $\mathbf{S}$ \\
\hline Australia & 3.09 & 0 & 0 & 1 & 0.63 & 0 \\
\hline Austria & 1.98 & 1 & 0 & 1 & 0.94 & 0 \\
\hline Azerbaijan & 6.07 & 0 & 0 & 0 & 0.63 & 0 \\
\hline Bahamas, The & 2.00 & 0 & 0 & 0 & 0.31 & 1 \\
\hline Bahrain & 0.87 & 0 & 0 & 0 & 0.44 & 1 \\
\hline Bangladesh & 5.36 & 0 & 0 & 0 & 0.19 & 0 \\
\hline Barbados & 3.10 & 0 & 0 & 0 & 0.38 & 1 \\
\hline Belarus & 30.10 & 0 & 0 & 0 & 0.44 & 0 \\
\hline Belgium & 2.05 & 1 & 0 & 1 & 0.94 & 0 \\
\hline Belize & 2.42 & 0 & 0 & 0 & 0.38 & 1 \\
\hline Benin & 2.85 & 1 & 0 & 0 & na & 0 \\
\hline Bermuda & na & 0 & 1 & 0 & 0.44 & 1 \\
\hline Bhutan & 3.70 & 0 & 0 & 0 & 0.31 & 1 \\
\hline Bolivia & 3.99 & 0 & 0 & 0 & 0.75 & 0 \\
\hline Bosnia \& Herzegovina & na & 0 & 1 & 0 & 0.88 & 1 \\
\hline Botswana & 7.68 & 0 & 0 & 0 & 0.44 & 1 \\
\hline Brazil & 6.79 & 0 & 0 & 1 & 0.63 & 0 \\
\hline Brunei Darussalam & 0.33 & 0 & 1 & 0 & na & 1 \\
\hline Bulgaria & 6.18 & 0 & 1 & 0 & 0.88 & 0 \\
\hline Burkina Faso & 2.09 & 1 & 0 & 0 & na & 0 \\
\hline Burundi & 8.62 & 0 & 0 & 0 & 0.38 & 0 \\
\hline Cambodia & 2.82 & 0 & 0 & 0 & 0.56 & 0 \\
\hline Cameroon & 2.12 & 1 & 0 & 0 & na & 0 \\
\hline Canada & 2.26 & 0 & 0 & 1 & 0.63 & 0 \\
\hline Cape Verde & 1.51 & 0 & 0 & 0 & 0.5 & 1 \\
\hline Cayman Islands & na & 0 & 1 & 0 & 0.38 & 1 \\
\hline Central African Rep. & 2.33 & 1 & 0 & 0 & na & 1 \\
\hline Chad & 2.59 & 1 & 0 & 0 & na & 0 \\
\hline Channel Islands & na & 0 & 0 & 0 & na & 1 \\
\hline Chile & 2.99 & 0 & 0 & 1 & 0.69 & 0 \\
\hline China & 1.60 & 0 & 0 & 0 & 0.56 & 0 \\
\hline Colombia & 6.03 & 0 & 0 & 1 & 0.5 & 0 \\
\hline Comoros & na & 0 & 0 & 0 & 0.44 & 1 \\
\hline Congo, Dem. Rep. & 61.04 & 0 & 0 & 0 & na & 0 \\
\hline Congo, Rep. & 2.14 & 1 & 0 & 0 & na & 1 \\
\hline Costa Rica & 9.89 & 0 & 0 & 0 & 0.69 & 1 \\
\hline Cote d'Ivoire & 2.78 & 1 & 0 & 0 & na & 0 \\
\hline Croatia & 2.83 & 0 & 0 & 0 & 0.88 & 1 \\
\hline Cuba & na & 0 & 0 & 0 & 0.31 & 0 \\
\hline Czech Republic & 2.52 & 0 & 0 & 1 & 0.88 & 0 \\
\hline Denmark & 2.01 & 0 & 0 & 0 & 0.75 & 0 \\
\hline Djibouti & na & 0 & 1 & 0 & na & 1 \\
\hline Dominica & 1.51 & 0 & 1 & 0 & na & 1 \\
\hline Dominican Republic & 12.91 & 0 & 0 & 0 & 0.56 & 0 \\
\hline Ecuador & 17.07 & 0 & 0 & 0 & 0.94 & 0 \\
\hline Egypt, Arab Rep. & 5.36 & 0 & 0 & 0 & 0.38 & 0 \\
\hline El Salvador & 3.35 & 0 & 0 & 0 & 0.81 & 0 \\
\hline Equatorial Guinea & 6.16 & 1 & 0 & 0 & na & 1 \\
\hline Eritrea & na & 0 & 0 & 0 & 0.5 & 1 \\
\hline Estonia & 3.94 & 0 & 1 & 0 & 0.81 & 1 \\
\hline Ethiopia & 6.57 & 0 & 0 & 0 & 0.5 & 0 \\
\hline
\end{tabular}


Appendix. (Continued).

\begin{tabular}{|c|c|c|c|c|c|c|}
\hline & $\begin{array}{c}\text { D } \\
\left({ }^{*} 100\right)\end{array}$ & $\begin{array}{c}\text { MU } \\
(1)\end{array}$ & $\begin{array}{r}\mathbf{C B} \\
(1)\end{array}$ & $\begin{array}{l}\text { IT } \\
(2)\end{array}$ & CBI & $\mathbf{S}$ \\
\hline Faeroe Islands & na & 0 & 1 & 0 & na & 1 \\
\hline Falkland Islands & na & 0 & 1 & 0 & na & 0 \\
\hline Fiji & 2.77 & 0 & 0 & 0 & 0.38 & 1 \\
\hline Finland & 1.66 & 1 & 0 & 1 & 0.94 & 0 \\
\hline France & 1.77 & 1 & 0 & 1 & 0.94 & 0 \\
\hline French Polynesia & na & 0 & 0 & 0 & na & 1 \\
\hline Gabon & 1.24 & 1 & 0 & 0 & na & 1 \\
\hline Gambia, The & 7.36 & 0 & 0 & 0 & na & 1 \\
\hline Georgia & 6.04 & 0 & 0 & 0 & 0.75 & 1 \\
\hline Germany & 1.63 & 1 & 0 & 1 & 0.88 & 0 \\
\hline Ghana & 16.49 & 0 & 0 & 0 & 0.5 & 0 \\
\hline Gibraltar & na & 0 & 1 & 0 & na & 0 \\
\hline Greece & 3.18 & 1 & 0 & 1 & 0.81 & 0 \\
\hline Greenland & na & 0 & 0 & 0 & na & 1 \\
\hline Grenada & 2.32 & 0 & 1 & 0 & na & 1 \\
\hline Guam & na & 0 & 0 & 0 & na & 1 \\
\hline Guatemala & 6.52 & 0 & 0 & 0 & 0.63 & 0 \\
\hline Guinea & na & 0 & 0 & 0 & 0.63 & 0 \\
\hline Guinea-Bissau & 2.74 & 1 & 0 & 0 & na & 1 \\
\hline Guyana & 5.94 & 0 & 0 & 0 & 0.5 & 1 \\
\hline Haiti & 14.63 & 0 & 0 & 0 & 0.5 & 0 \\
\hline Honduras & 7.57 & 0 & 0 & 0 & 0.5 & 0 \\
\hline Hong Kong, China & -0.82 & 0 & 1 & 0 & 0.38 & 0 \\
\hline Hungary & 6.00 & 0 & 0 & 1 & 0.94 & 0 \\
\hline Iceland & 4.48 & 0 & 0 & 1 & 0.75 & 1 \\
\hline India & 4.32 & 0 & 0 & 0 & 0.5 & 0 \\
\hline Indonesia & 8.04 & 0 & 0 & 0 & 0.69 & 0 \\
\hline Iran, Islamic Rep. & 12.46 & 0 & 0 & 0 & 0.38 & 0 \\
\hline Iraq & na & 0 & 0 & 0 & 0.63 & 0 \\
\hline Ireland & 3.85 & 1 & 0 & 1 & 0.81 & 1 \\
\hline Isle of Man & na & 0 & 0 & 0 & na & 1 \\
\hline Israel & 1.50 & 0 & 0 & 1 & 0.38 & 0 \\
\hline Italy & 2.27 & 1 & 0 & 1 & 0.81 & 0 \\
\hline Jamaica & 9.02 & 0 & 0 & 0 & 0.38 & 1 \\
\hline Japan & -0.32 & 0 & 0 & 0 & 0.44 & 0 \\
\hline Jordan & 2.96 & 0 & 0 & 0 & 0.38 & 0 \\
\hline Kazakhstan & 7.79 & 0 & 0 & 0 & 0.75 & 0 \\
\hline Kenya & 8.43 & 0 & 0 & 0 & 0.44 & 0 \\
\hline Kiribati & na & 0 & 0 & 0 & na & 1 \\
\hline Korea, Dem. Rep. & na & 0 & 0 & 0 & na & 0 \\
\hline Korea, Rep. & 2.87 & 0 & 0 & 1 & 0.56 & 0 \\
\hline Kuwait & 2.39 & 0 & 0 & 0 & 0.31 & 1 \\
\hline Kyrgyz Republic & 6.43 & 0 & 0 & 0 & 0.88 & 0 \\
\hline Lao PDR & 9.91 & 0 & 0 & 0 & 0.38 & 0 \\
\hline Latvia & 4.72 & 0 & 0 & 0 & 1 & 1 \\
\hline Lebanon & na & 0 & 0 & 0 & 0.5 & 1 \\
\hline Lesotho & 6.92 & 0 & 0 & 0 & 0.44 & 1 \\
\hline Liberia & na & 0 & 0 & 0 & 0.5 & 1 \\
\hline Libya & -3.02 & 0 & 0 & 0 & 0.44 & 0 \\
\hline Liechtenstein & na & 0 & 0 & 0 & na & 1 \\
\hline Lithuania & 1.82 & 0 & 1 & 0 & 0.81 & 1 \\
\hline
\end{tabular}


Appendix. (Continued).

\begin{tabular}{|c|c|c|c|c|c|c|}
\hline & $\begin{array}{c}\text { D } \\
\left({ }^{*} 100\right)\end{array}$ & $\begin{array}{c}\text { MU } \\
(1)\end{array}$ & $\begin{array}{l}\text { CB } \\
(1)\end{array}$ & $\begin{array}{l}\mathbf{I T} \\
(2)\end{array}$ & CBI & $\mathbf{S}$ \\
\hline Luxembourg & 2.40 & 1 & 0 & 1 & 0.94 & 1 \\
\hline Macao, China & 1.03 & 0 & 0 & 0 & 0.44 & 1 \\
\hline Macedonia, FYR & 2.82 & 0 & 0 & 0 & 0.88 & 0 \\
\hline Madagascar & 9.81 & 1 & 0 & 0 & 0.63 & 0 \\
\hline Malawi & 13.55 & 0 & 0 & 0 & 0.38 & 0 \\
\hline Malaysia & 1.94 & 0 & 0 & 0 & 0.5 & 0 \\
\hline Maldives & 5.14 & 0 & 0 & 0 & 0.38 & 1 \\
\hline Mali & 1.78 & 1 & 0 & 0 & na & 0 \\
\hline Malta & 2.28 & 1 & 0 & 1 & 0.69 & 1 \\
\hline Marshall Islands & na & 0 & 0 & 0 & na & 1 \\
\hline Mauritania & 6.22 & 0 & 0 & 0 & na & 1 \\
\hline Mauritius & 5.64 & 0 & 0 & 0 & 0.5 & 1 \\
\hline Mayotte & na & 0 & 0 & 0 & na & 1 \\
\hline Mexico & 4.95 & 0 & 0 & 1 & 0.69 & 0 \\
\hline Micronesia, Fed. Sts. & na & 0 & 0 & 0 & na & 1 \\
\hline Moldova & 11.87 & 0 & 0 & 0 & 0.75 & 1 \\
\hline Monaco & na & 0 & 0 & 0 & 0.75 & 1 \\
\hline Mongolia & 6.87 & 0 & 0 & 0 & na & 1 \\
\hline Montenegro & na & 0 & 0 & 0 & na & 1 \\
\hline Morocco & 1.76 & 0 & 0 & 0 & 0.5 & 0 \\
\hline Mozambique & 10.43 & 0 & 0 & 0 & 0.44 & 0 \\
\hline Myanmar & 18.67 & 0 & 0 & 0 & 0.38 & 0 \\
\hline Namibia & 4.83 & 1 & 0 & 0 & 0.38 & 1 \\
\hline Nepal & 4.44 & 0 & 0 & 0 & 0.5 & 0 \\
\hline Netherlands & 2.17 & 1 & 0 & 1 & 0.88 & 0 \\
\hline Netherlands Antilles & 2.59 & 0 & 0 & 0 & 0.44 & 1 \\
\hline New Caledonia & na & 0 & 0 & 0 & na & 1 \\
\hline New Zealand & 2.52 & 0 & 0 & 1 & 0.44 & 1 \\
\hline Nicaragua & 7.32 & 0 & 0 & 0 & 0.56 & 0 \\
\hline Niger & 1.97 & 1 & 0 & 0 & na & 0 \\
\hline Nigeria & 11.03 & 0 & 0 & 0 & 0.44 & 0 \\
\hline Northern Mariana Islands & na & 0 & 0 & 0 & na & 0 \\
\hline Norway & 1.83 & 0 & 0 & 1 & 0.75 & 1 \\
\hline Oman & 1.52 & 0 & 0 & 0 & 0.31 & 1 \\
\hline Pakistan & 5.41 & 0 & 0 & 0 & 0.5 & 0 \\
\hline Palau & na & 0 & 0 & 0 & na & 1 \\
\hline Panama & 1.57 & 0 & 1 & 0 & 0.38 & 1 \\
\hline Papua New Guinea & 6.83 & 0 & 0 & 0 & 0.63 & 0 \\
\hline Paraguay & 8.03 & 0 & 0 & 0 & 0.5 & 0 \\
\hline Peru & 2.11 & 0 & 0 & 1 & 0.69 & 0 \\
\hline Philippines & 4.74 & 0 & 0 & 1 & 0.63 & 0 \\
\hline Poland & 3.32 & 0 & 0 & 1 & 0.88 & 0 \\
\hline Portugal & 2.94 & 1 & 0 & 1 & 0.81 & 0 \\
\hline Puerto Rico & na & 0 & 0 & 0 & na & 1 \\
\hline Qatar & 5.53 & 0 & 0 & 0 & 0.19 & 1 \\
\hline Romania & 15.81 & 0 & 0 & 0 & 0.69 & 0 \\
\hline Russian Federation & 12.46 & 0 & 0 & 0 & 0.44 & 0 \\
\hline Rwanda & 6.53 & 0 & 0 & 0 & 0.56 & 0 \\
\hline S. Cyprus & 2.77 & 0 & 0 & 1 & 0.56 & 0 \\
\hline Samoa & 4.82 & 0 & 0 & 0 & na & 1 \\
\hline San Marino & na & 0 & 0 & 0 & na & 1 \\
\hline
\end{tabular}


Appendix. (Continued).

\begin{tabular}{|c|c|c|c|c|c|c|}
\hline & $\begin{array}{c}\text { D } \\
\left({ }^{*} 100\right)\end{array}$ & $\begin{array}{c}\text { MU } \\
(1)\end{array}$ & $\begin{array}{l}\text { CB } \\
\text { (1) }\end{array}$ & $\begin{array}{l}\text { IT } \\
(2)\end{array}$ & CBI & $\mathbf{S}$ \\
\hline Sao Tome and Principe & na & 0 & 0 & 0 & 0.31 & 1 \\
\hline Saudi Arabia & 0.74 & 0 & 0 & 0 & 0.5 & 0 \\
\hline Senegal & 1.98 & 1 & 0 & 0 & na & 0 \\
\hline Serbia & 23.13 & 0 & 0 & 0 & na & 0 \\
\hline Seychelles & 3.08 & 0 & 0 & 0 & 0.25 & 1 \\
\hline Sierra Leone & 6.22 & 0 & 0 & 0 & 0.56 & 0 \\
\hline Singapore & 0.95 & 0 & 0 & 0 & 0.38 & 1 \\
\hline Slovak Republic & 5.74 & 1 & 0 & 1 & 0.63 & 0 \\
\hline Slovenia & 5.04 & 1 & 0 & 1 & 0.81 & 1 \\
\hline Solomon Islands & 7.75 & 0 & 0 & 0 & 0.38 & 1 \\
\hline Somalia & na & 0 & 0 & 0 & na & 0 \\
\hline South Africa & 5.05 & 0 & 0 & 1 & 0.25 & 0 \\
\hline Spain & 3.13 & 1 & 0 & 1 & 0.88 & 0 \\
\hline Sri Lanka & 9.76 & 0 & 0 & 0 & 0.56 & 0 \\
\hline St. Helena & na & 0 & 1 & 0 & na & 0 \\
\hline St. Kitts and Nevis & 2.04 & 0 & 1 & 0 & na & 1 \\
\hline St. Lucia & 2.44 & 0 & 1 & 0 & na & 1 \\
\hline St. Vincent \& the Grenadines & 1.66 & 0 & 1 & 0 & na & 1 \\
\hline Sudan & 7.05 & 0 & 0 & 0 & 0.31 & 0 \\
\hline Suriname & 19.34 & 0 & 0 & 0 & 0.38 & 1 \\
\hline Swaziland & 6.79 & 1 & 0 & 0 & na & 1 \\
\hline Sweden & 1.45 & 0 & 0 & 1 & 0.94 & 0 \\
\hline Switzerland & 0.94 & 0 & 0 & 1 & 0.94 & 0 \\
\hline Syrian Arab Republic & 3.65 & 0 & 0 & 0 & 0.44 & 0 \\
\hline Tajikistan & 12.99 & 0 & 0 & 0 & 0.81 & 0 \\
\hline Tanzania & 4.50 & 0 & 0 & 0 & 0.38 & 0 \\
\hline Thailand & 2.42 & 0 & 0 & 1 & 0.44 & 0 \\
\hline Timor-Leste & 4.90 & 0 & 0 & 0 & 0.69 & 1 \\
\hline Togo & 2.24 & 1 & 0 & 0 & na & 0 \\
\hline Tonga & 8.18 & 0 & 0 & 0 & 0.31 & 1 \\
\hline Trinidad and Tobago & 5.20 & 0 & 0 & 0 & 0.44 & 1 \\
\hline Tunisia & 2.87 & 0 & 0 & 0 & 0.69 & 0 \\
\hline Turkey & 21.54 & 0 & 0 & 1 & 0.81 & 0 \\
\hline Turkmenistan & na & 0 & 0 & 0 & 0.69 & 1 \\
\hline Uganda & 4.38 & 0 & 0 & 0 & 0.56 & 0 \\
\hline Ukraine & 10.18 & 0 & 0 & 0 & 0.81 & 0 \\
\hline United Arab Emirates & na & 0 & 0 & 0 & 0.44 & 1 \\
\hline United Kingdom & 2.74 & 0 & 0 & 1 & 0.69 & 0 \\
\hline United States & 2.70 & 0 & 0 & 0 & 0.75 & 0 \\
\hline Uruguay & 8.14 & 0 & 0 & 0 & 0.63 & 1 \\
\hline Uzbekistan & na & 0 & 0 & 0 & 0.69 & 0 \\
\hline Vanuatu & 2.18 & 0 & 0 & 0 & 0.38 & 1 \\
\hline Venezuela, RB & 15.99 & 0 & 0 & 0 & 0.69 & 0 \\
\hline Vietnam & 4.38 & 0 & 0 & 0 & 0.44 & 0 \\
\hline Virgin Islands (U.S.) & na & 0 & 0 & 0 & na & 1 \\
\hline West Bank and Gaza & 3.33 & 0 & 0 & 0 & na & 1 \\
\hline Yemen, Rep. & 10.80 & 0 & 0 & 0 & 0.44 & 0 \\
\hline Zambia & 15.53 & 0 & 0 & 0 & 0.44 & 0 \\
\hline Zimbabwe & 97.10 & 0 & 0 & 0 & 0.44 & 0 \\
\hline
\end{tabular}

(1) Fund Surveillance Over Members of Currency Unions, IMF, December 21, 2005.

(2) Petursson (2004), Roger and Stone (2005). 